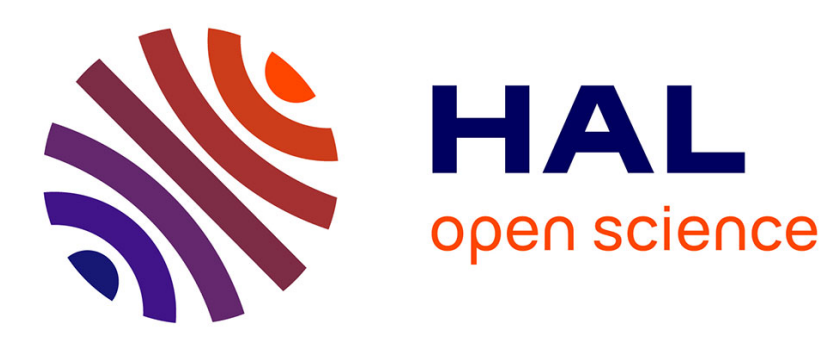

\title{
Calculation of the Reversible Permeability of Gapped Cores from Measured Ring Core Data
}

\author{
D. Lange
}

\section{To cite this version:}

D. Lange. Calculation of the Reversible Permeability of Gapped Cores from Measured Ring Core Data. Journal de Physique IV Proceedings, 1997, 07 (C1), pp.C1-137-C1-138. 10.1051/jp4:1997146 . jpa-00255093

\section{HAL Id: jpa-00255093 https://hal.science/jpa-00255093}

Submitted on 1 Jan 1997

HAL is a multi-disciplinary open access archive for the deposit and dissemination of scientific research documents, whether they are published or not. The documents may come from teaching and research institutions in France or abroad, or from public or private research centers.
L'archive ouverte pluridisciplinaire HAL, est destinée au dépôt et à la diffusion de documents scientifiques de niveau recherche, publiés ou non, émanant des établissements d'enseignement et de recherche français ou étrangers, des laboratoires publics ou privés. 


\title{
Calculation of the Reversible Permeability of Gapped Cores from Measured Ring Core Data
}

\author{
D. Lange
}

Siemens Matsushita Components GmbH \& Co KG, S+M FER M PD, P.O. Box 801709, 81617 Munich, Germany

\begin{abstract}
In ferrite data books the reversible permeability for small excitation levels is usually given vs. external dc magnetic field for different values of the effective permeability. To determine these curves the incremental permeability has to be measured on cores with different air gaps. Due to the grinding of different air gaps the determination of those curves is very costly. Also a judgement of the incremental permeability from ring cores, which are used in the material development, is not possible.

In this paper the calculation of the incremental permeability for cores with homogeneous cross section from measured data of ring cores is presented. The reversible permeability vs. dc magnetic field and the amplitude permeability vs. flux density has to be measured. With those data the reversible permeability vs. flux density for the ring core can be calculated. Gans made the assumption that the reversible permeability vs. flux density is a material property. By calculating the drop of the flux density due to an air gap the incremental permeability for a gapped core with homogeneous cross section can be calculated as a function of the external dc magnetic field.

Calculated and measured data for E-cores made of the $\mathrm{S}+\mathrm{M}$ material $\mathrm{N} 87$ are in excellent accordance.
\end{abstract}

\section{INTRODUCTION}

For the design of chokes the incremental permeability for small excitation levels, also called reversible permeability $\mu_{\mathrm{rev}}$, is an important property. In ferrite data books $\mu_{\mathrm{rev}}$ is given as a function of the applied dc magnetic field $\mathrm{H}_{\mathrm{dc}}$ for only several values of the effective permeability. To get intermediate values those curves has to be graphically interpolated, which is difficult due to the logarithmic scale of the plots. The calculation of $\mathrm{H}_{\mathrm{dc}}$, at which $\mu_{\mathrm{rev}}$ is decreased about $10 \%$ against the effective permeability was given in [1]. Based on Gans assumption that $\mu_{\text {rev }}$ as a function of flux density B is a material property [2], $\mu_{\mathrm{rev}}$ can be calculated as a function of $\mathrm{H}_{\mathrm{dc}}$ for cores with any air gap. $\mu_{\mathrm{rev}}(\mathrm{B})$ has to be determined from measured ring core data. For the calculation of $\mu_{\mathrm{rev}}$ vs. $\mathrm{H}_{\mathrm{dc}}$ the influence of the air gap on $\mu_{\mathrm{rev}}$ and on the relationship between the applied dc magnetic field and the flux density has to be determined.

\section{DETERMINATION OF $\mu_{\mathrm{rev}}($ B) FROM RING CORE DATA}

With common measurement techniques $\mu_{\mathrm{rev}}$ vs. $\mathrm{H}_{\mathrm{dc}}$ can be measured on ring cores. To get $\mu_{\mathrm{rev}}$ vs. $\mathrm{B}$ the flux density has to be calculated. The relationship between $\mathrm{H}_{\mathrm{dc}}$ and $\mathrm{B}$ gives the fundamental equation

$$
\mathrm{H}_{\mathrm{dc}}=\frac{\mathrm{B}}{\mu_{\mathrm{i}}(\mathrm{B}) \cdot \mu_{\mathrm{i}}} \text {. }
$$

For ring cores $\mathrm{H}_{\mathrm{dc}}$ is identical with the magnetic field in the material $\mathrm{H}_{\mathrm{int}} \mu_{\mathrm{a}}(\mathrm{B})$ can be measured on the commutation curve [4] if assumed that the commutation curve is identical to the initial magnetization curve [4].

\section{INFLUENCE OF AIR GAP}

The influence of an air gap applied into a magnetic circuit can be described with the demagnetization factor $ß[5]$. 


$$
B=\frac{1}{\mu_{e}}-\frac{1}{\mu_{i}}
$$

$\mu_{\mathrm{e}}$ is the effective permeability of the magnetic circuit with air gap and $\mu_{\mathrm{i}}$ is the initial permeability of the material. If the flux density is constant over the magnetic path the same equation is valid for the relationship between the effective reversible permeability $\mu_{\text {erev }}$ of the magnetic circuit with air gap and $\mu_{\mathrm{rev}}(\mathrm{B})$ of the material. This is valid for cores with constant cross section over the magnetic path. Hence $\mu_{\text {erev }}$ can be described as a function of $B$.

$$
\mu_{\text {erev }}(B)=\left(\frac{1}{\mu_{\text {rev }}(B)}+B\right)^{-1}
$$

Due to an air gap the magnetic field $\mathbf{H}_{\text {int }}$ in the material is lower than the applied magnetic field $\mathbf{H}_{d c}$.

$$
\mathrm{H}_{\mathrm{int}}=\mathrm{H}_{\mathrm{dc}}-\frac{\beta}{\mu_{0}} \cdot \mathbf{B}
$$

With equation (1) the applied magnetic field can be described as a function of flux density.

$$
\mathrm{H}_{\mathrm{dc}}(\mathrm{B})=\frac{\mathrm{B}}{\mu_{\mathrm{a}}(\mathrm{B}) \cdot \mu_{0}}+\frac{\mathrm{B}}{\mu_{0}} \cdot \mathrm{B}
$$

With the ring core data $\mu_{\text {rev }}(B)$ and $\mu_{a}(B)$ both $\mu_{\text {erev }}$ and $\mathrm{H}_{\mathrm{dc}}$ are given as a function of flux density and hence the function $\mu_{\text {erev }}\left(\mathrm{H}_{\mathrm{dc}}\right)$ is given.

\section{RESULTS}

$\mu_{\text {erev }}\left(\mathrm{H}_{\mathrm{d} c}\right)$ was measured on ETD44 cores in the material $\mathrm{N} 87$ at $\mathrm{T}=25^{\circ} \mathrm{C}$. The initial permeability of $\mathrm{N} 87$ is 2200 . The N87 material data $\mu_{\mathrm{rev}}\left(\mathrm{H}_{\mathrm{dc}}\right)$ and $\mu_{\mathrm{a}}(\mathrm{B})$ for the calculation of $\mu_{\mathrm{rev}}\left(\mathrm{H}_{\mathrm{dc}}\right)$ were measured on R29 cores at $\mathbf{T}=$ $25^{\circ} \mathrm{C}$. The demagnetization factor $B$ was calculated with measured values of the effective permeability of the ETD44 cores and with the nominal initial permeability of N87.

Figure 1 shows a comparison of measured and calculated data.

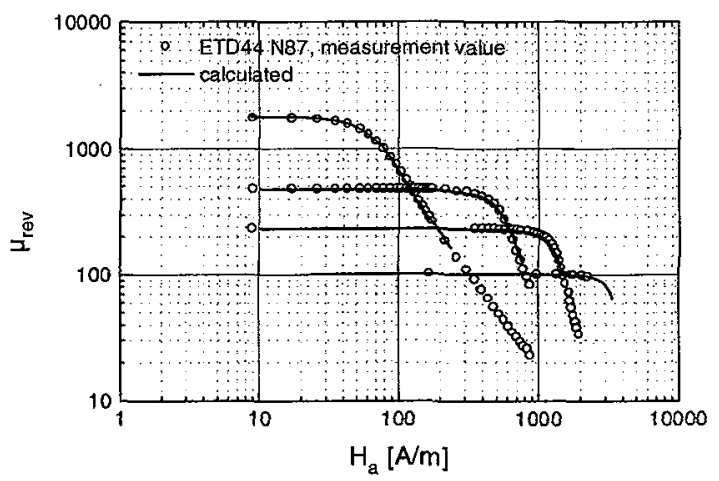

Figure 1: Comparison of measured and calculated data for an ETD44 core in the $\mathrm{S}+\mathrm{M}$ Material $\mathrm{N} 87$ at $\mathrm{T}=25^{\circ} \mathrm{C}$

\section{References}

[1] Lange D, "Berechnung von Grenzdaten bei der Gleichstromvormagnetisierung", Conference on electronica, Munich November 1992

[2] Gans R., "Die Gleichung der Kurve der reversiblen Suszeptibilität", Phys. Z. 12 (1911), pp 1053 - 1054

[3] Bozorth, R., "Ferromagnetism", (Van Nostrand Company, Inc., 1951), p 6

[4] Kampczyk W, RöB E., "Ferritkerne", (Siemens AG, 1978), pp 170 - 172

[5] Kampczyk W, Röß E., "Ferritkerne", (Siemens AG, 1978), pp 250 ff 